Case Report

\title{
Embedding Sustainability in the Consumer Goods Innovation Cycle and Enabling Tools to Measure Progress and Capabilities
}

\author{
Prateek Jain ${ }^{1, \dagger}$, Mabel C. Chou ${ }^{2,3, * \mathbb{D} \text {, Faith Fan }}{ }^{4, \ddagger}$ and Michelle Permata Santoso ${ }^{5, \S}$ \\ 1 Nutrition \& Health and Wellness International Markets Division, Unilever, Singapore 117439, Singapore; \\ Prateek.jaink@unilever.com \\ 2 Institute of Operations Research and Analytics, National University of Singapore, \\ Singapore 117602, Singapore \\ 3 Department of Analytics and Operations, NUS Business School, National University of Singapore, \\ Singapore 119245, Singapore \\ 4 Private Address, Singapore 000000, Singapore; evanescentce@gmail.com \\ 5 APAC Supply Chain Strategy \& Transformation, GlaxoSmithKline, Singapore 139234, Singapore; \\ michelle.x.santoso@gsk.com \\ * Correspondence: mabelchou@nus.edu.sg \\ + Prateek Jain is the Head of Nutrition for International Markets, Unilever and Chairman for Eurocham Supply \\ Chain Committee Singapore. \\ $\ddagger \quad$ Faith Fan is an Order Execution Analyst in a major multinational corporation. \\ $\S$ Michelle Permata Santoso is the APAC Supply Chain Strategy and Transformation Project Manager \\ at GlaxoSmithKline.
}

check for updates

Citation: Jain, P.; Chou, M.C.; Fan, F.; Santoso, M.P. Embedding

Sustainability in the Consumer Goods Innovation Cycle and Enabling Tools to Measure Progress and Capabilities. Sustainability 2021, 13, 6662. https:// doi.org/10.3390/su13126662

Academic Editor: António Abreu

Received: 29 April 2021

Accepted: 4 June 2021

Published: 11 June 2021

Publisher's Note: MDPI stays neutral with regard to jurisdictional claims in published maps and institutional affiliations.

Copyright: (c) 2021 by the authors. Licensee MDPI, Basel, Switzerland. This article is an open access article distributed under the terms and conditions of the Creative Commons Attribution (CC BY) license (https:/ / creativecommons.org/licenses/by/ $4.0 /)$.

\begin{abstract}
This paper highlights the mutual relationship and crucial need for sustainability in innovation and vice versa, with a focus on various companies that are leading in this aspect. Together with certain conditions in place, growing awareness of this need has led to these companies achieving groundbreaking progress in embedding sustainability into the new product innovation space via the development of an overarching roadmap supported by strategic partnerships and robust quantitative tools, to proactively expand the sustainability mindset and way of life into the company culture and ways of working. Case studies of these companies are examined, and based on the findings, the paper concludes with recommendations and next steps for businesses to take to succeed in sustainability-centric innovation.
\end{abstract}

Keywords: sustainability-centric innovation; circular economy; roadmap; quantitative tools

\section{Introduction}

The 20th century has been a period of unprecedented industrial growth and societal advancement, which has led to exponential growth in energy use, natural resource depletion and a rise of varied problems relating to sustainability, especially in the environmental space [1]. In recent years, growing recognition among consumers about such negative environmental impacts has spurred both governments and companies to address these issues. This is because the demand for sustainability-focused goods and services has increased. For example, previous research published in year 2020 has indicated that $72 \%$ of Gen $\mathrm{Z}$ consumers are willing to spend more on a sustainably produced service, and $59 \%$ of consumers across all age groups believed that it was important that the foods they bought were consumed sustainably, an increase from 50\% in 2017 [2]. In response to this trend, governments have started to impose greater environmental and social regulations on companies. For instance, in 2018, US legislation proposed an ambitious commitment to a $75 \%$ reduction in plastic statewide within 10 years, requiring all single-use packaging produced, sold and distributed in California to be fully recyclable or compostable by 2030 [3]. Moreover, in 2018, European Parliament voted on its first report of the rights of indigenous people around the world, calling their rights to be fully protected [4], while companies 
have begun examining inherent inefficiencies in their businesses to modify operational practices to stay relevant while meeting such regulations.

According to Deloitte [5], brands are also increasingly in the spotlight from a consumer perspective where consumers, especially millennials, are expecting businesses to operate at the highest possible standards and want explicit reassurance that what they buy is good for the planet. Digitally empowered consumers are also relying on independent, credible sources to find information on brands and products that are readily available online. Companies that are not driving this agenda often find themselves grounded in unwelcomed publicity. Considering the external pressures, this has led to the growth of an entrepreneurial and competitive sustainability movement among companies to reduce their ecological footprints [6]. In addition, the consumer mindset paints companies as the main reason behind social and environmental problems and the source of the lack of sustainability in society [7]. This means that consumers expect companies to act as main agents of change to promote and champion sustainability. Beyond leveraging the sustainability concept to improve brand reputations and operational efficiency and lower costs [8], companies also need to connect regularly with consumers regarding a brand's purpose, consistently showing the benefits of sustainable option compared to traditional ones and ensuring that sustainability is an irresistible option [9]. However, communicating a product's sustainable attributes must be accomplished with genuine intent and real action from the company. There is a risk of consumers falling into the trap of greenwashing, where organizations mislead consumers through false advertising by emphasizing or exaggerating green features of the products in order to attract consumers [10]. Greenwashing techniques such as vague, false and irrelevant labels are used to promote goods and services. The incentive to advertise sustainable claims has never been more attractive, as sales of "environmentally friendly" goods and services passed GBP 41 billion in the United Kingdom in 2019 [11]. Green advertising, greenwashed or not, has been shown to affect consumers' perception of a product's level of sustainability. There is evidence showing that even consumers with more expertise in environmental issues are not fully resistant to greenwashing advertisements, wrongly identifying greenwashed products as sustainable ones [12]. It is also suggested that consumers' awareness of greenwashing is rather limited, as they perceive brands with green advertising to be more environmentally friendly [13]. This shows that consumers are not evaluating claims in-depth and are simply trusting the green advertising presented [14]. This shows a need for greater awareness on consumers end of what is considered to be genuinely sustainable, and they must know how to critically evaluate a company's real action towards furthering the sustainability agenda. This puts responsibility on companies to communicate fairly and educate consumers about how deceptive and misleading greenwashing advertisements could be. External organizations can play a role to increase consumers' awareness. One good example is a documentary on Netflix called "Seaspiracy", which generated heightened consumer awareness of greenwashed fish labels. Presently, there is minimal regulation, policy and scrutiny in this space. However, this is expected to shift, with a review outcome expected in 2021 by the UK government to heighten control on greenwashing to avoid misleading consumers [11].

Apart from playing a critical role of educating consumers, the role of sustainable products should not be underestimated as it brings about environmental, social and economic benefits compared to non-sustainable options. It has encouraged companies to develop sustainable innovation portfolios, creating healthy competition for companies to accelerate the speed of innovation in the market. A review of sustainability business models showed firms that pursue first-mover advantages can gain competitive advantages, thereby improving the sustainable development goals of the firm [15-22].

Sustainability provides a performance outcome, quality image perception, input preemption, innovation leadership and economic scale advantage to the company [23]. Beyond such benefits, it has challenged companies to re-evaluate their end-to-end value chain to reduce their environmental and social impacts throughout. Beyond innovating for products with better sustainability credentials, companies are forced to think innovatively about 
the product's end of life strategy, avoiding disposal to landfills at all costs. For example, in recent years, there has been a shift from using fossil fuel to bio-based products, which is potentially a more sustainable option as it claims to generate less waste, energy and water [24]. These raw materials are typically input to the packaging seen in our daily lives. With the rise of such alternative solutions, there needs to be a holistic circularity assessment that includes social and economic factors to assess the effectiveness of such solutions. A study conducted by Adamo, Falcone, Imbert and Morone resulted in the development of socio-economic criterion to assess various end-of-life options of bio-based plastic. In the study, it was shown that mechanical recycling is the best option for polyactic acid-based film for food packaging [25]. This could be used to guide companies to holistically assess the best end-of-life options for their sustainable packaging initiatives. Companies can also adopt similar methodologies to assess their sustainability innovation portfolios. In terms of circularity, new markets have also emerged from developments in sustainable packaging. One example is "The New Plastics Economy", where the circular economy for plastics is being driven by multiple stakeholders in the market with rigorous targets and initiatives in place. Companies are also setting sustainable goals to launch packaging with recycled components, opening a new market of recycled and upcycled plastic. One notable sustainable innovation example came from Procter \& Gamble (P\&G) launching a Head and Shoulders bottle made up of ocean plastic [26]. Hence, sustainable products have played a pivotal role in educating consumers, challenging the limits of sustainable innovation while improving speed into market.

Government regulations and companies' traditional focus on reducing energy and wastage in their operations is not enough to ensure the security, health and vitality of the natural environment for future generations. It is important to implement the concept of sustainability-centric innovation [27] whereby business innovation is successfully tied with an environmentalist mindset of natural resource protection to bring about the launch of breakthrough products and services that advance societal goals of human health, equity and environmental justice [27]. Sustainability has encouraged companies to undertake a different approach to innovating in the 21st century. It has pushed companies to adopt ambitious goals in terms of operations and innovation strategies. It has also transformed companies' innovation models to holistically include sustainability parameters encompassing environmental, social and economic aspects. It is fundamentally necessary for companies to have a genuine intent and real action in place in order to be successful in sustainability-centric innovation and gain consumers' trust. Furthermore, it is shown that successful companies have a sustainability champion mindset, making a difference through leveraging their networks and resources. These qualities should be reflected through a governance structure, supported by the usage of indices and collaboration with internal and external partners. Besides pushing the boundaries of innovation, it is imperative that companies embed sustainability closely into their overarching company strategy. It is not enough to merely consider sustainability-centric innovation in one aspect of the value chain, it is imperative for it to be integrated end-to-end to generate even greater payoffs and better manage risks.

To make a compelling case for companies to embed sustainability in innovation to strategically drive organic business growth [28], this paper includes various sections covering literature review, SWOT (Strengths, Weaknesses, Opportunities, Threats) analysis for selected companies, key insights and recommendations and conclusions. Section 2, the literature review, discusses current research on the relationship between sustainability and innovation, and the thesis of the need to embed sustainability in innovation. In Section 3, the SWOT analysis of selected companies, an analysis of strengths, weaknesses and threats to sustainability strategies of selected companies known to be market leaders in their own industries for sustainability-centric innovation is presented. The section also discusses opportunities for future expansion of these strategies. In Section 4, key insights and recommendations are covered. Based on Sections 2 and 3, a SWOT summary table for selected companies with a corresponding similarities vs. differences table is provided, 
linking to the key insights. Consequently, a recommended process flow and high-level steps are proposed to guide companies on what they should do to develop sustainabilitycentric innovation in their business models. In Section 5, the conclusion will wrap up key findings and takeaways for companies in relation to sustainability-centric innovation.

\section{Literature Review}

\subsection{Why Sustainability in Innovation}

Sustainability is defined as the quality of being able to continue over a period of time, according to the Cambridge Dictionary. Innovation is defined as a new method, idea or product that has the potential to drive economic growth, improve environmental credentials and tackle social issues, as well. Sustainability innovation can be defined as "economic development through the creation of private and social wealth to ultimately eliminate harmful impacts on communities, health and ecological systems" [29]. In the context of companies, the term sustainability innovation applies to improving products, services, processes and supply chains with environmental, social and economic improvements in mind. This includes a company's overarching sustainability strategy and goals.

Sustainability-centric innovation supported with a robust plan and data collection process, according to McKinsey, can significantly cut expenses and have a 60\%impact on operating profitability. It also reduces energy and water consumption. For example, Puma's data on the amount of water utilized and carbon emitted throughout its supply chain assisted in identifying $60 \%$ reductions in water, energy and fuel consumption [30]. By incorporating sustainability into business divisions, an organization's chances of benefitting from its sustainability efforts are enhanced [30].

Rafi [30] also states that being sustainable is critical in appealing to new hires. Approximately $40 \%$ of millennials have accepted a job because of the firm's sustainability efforts, and many are even willing to take a wage sacrifice to work for a firm that is environmentally conscious. As millennials now account for most of the workforce, failing to develop a long-term sustainability strategy could result in a loss of valuable talent.

Dyck and Silvestre [31] also states that growing global awareness of environmental and social crises has brought about the need for more sustainable lifestyles. Hence, as veteran scholar Kotler [32] states, it is imperative for businesses to reduce environmental degradation drastically as it poses danger to society in terms of accelerating climate change, freshwater shortages and natural resource depletions. To become sustainable, firms must make significant changes in their approach to business and Kohler calls this "environmental imperative". For Schaltegger, Lüdeke-Freund and Hansen [33], business activities are responsible for numerous social and environmental issues, hence it is crucial for businesses to be concerned about sustainability and be accountable in addressing these. In the views of these researchers, organizations have a critical role to play in facing these crises by leveraging their vast resources to implement innovations to promote sustainable development. In addition, Charter and Clark [34] has hypothesized that increasing recognition of the link between entrepreneurship, novel products and services to sustainability-centric innovation has birthed the concept that companies should practice such a style of innovation due to their economic networks and capabilities, which would make the creation of such breakthrough products possible to further the sustainability agenda.

Hansen, Grosse-Dunker and Reichwald [35] have also noted that sustainability-centric innovation is a powerful framework promoting penetration of new customer and market segments, which adds positive value to a company's global capital. A study conducted by Kim and Lee [36] suggests that consumer's connection to brands and trust is positively impacted by consumer's perceptions of sustainable supply chain practices in a company. This in turn strengthens the consumer's intention to purchase the product and pay a premium price. Chladek [37] also states that according to a 2019 survey, $73 \%$ of worldwide customers are eager to adjust their purchase habits to reduce their negative environmental effect, and sustainable product sales have increased by nearly $20 \%$ since 2014 . Millennials, in particular, are more prepared to spend a higher price for products that use sustainable 
materials or claim to be socially responsible. Therefore, if a company commits to environmentally friendly products and practices, it may be able to gain market share by converting environmentally conscious customers to brand-loyal ones and increase their revenue. For example, in the case of consumer products giant Unilever, they pledged to only use palm oil from verified sustainable sources since 2008. To spearhead an industry-wide use of sustainable palm oil, the company collaborated with its competitors, governments, NGOs and indigenous peoples' organizations. The reason for using palm oil is because it is inexpensive, adaptable and a common ingredient in packaged goods, yet its extraction has resulted in unprecedented levels of greenhouse gas emissions, contributing to global warming. By securing a head start in trailblazing the use of sustainable palm oil, Unilever continues to prosper, and the world benefits from sustainable palm oil harvesting methods [37].

More importantly and interestingly, consumption of "green products", the output of sustainability-centric innovation, has demonstrated enhancement of consumers' enjoyment in an effect known "green consumption". Green consumption is driven by warm glow, which is defined as feeling good about oneself after engaging in a prosocial behavior [38]. Based on five experiments conducted in actual consumption settings, Tezer and Bodur [38] has shown that consumers perceive an increase in their social worth - the extent to which they perceive themselves as valued as an individual by society (Grant and Gino, 2010) [39] — when they consume green products. This perception leads to warm glow and consequently an enhancement of consumption experiences, which suggests green consumption improves consumer well-being beyond the products' environmental benefits. Beyond consumers, it is important to look at benefits to employees as well. Previous studies by MIT $[40,41]$ have shown that the key pre-condition for sustainability innovation is a close connection between "individual purpose and corporate purpose" where employees understand the link between the company's long-term interests with the betterment of society. A clear roadmap is needed for employees to recognize how sustainability fits into the company's overarching strategy, which should be aligned with consumers' mindset [42]. More importantly, the roadmap should send a strong message to employees that sustainability is a way of life and motivate them to make positive changes in their lifestyles in and out of work to leave behind a better world for future generations to live in.

Therein lies the challenge for companies to innovate while maintaining sustainable development, by creating real value to enhance products and services while minimizing adverse socio-environmental impacts from business activities. In fact, such innovations are incremental and difficult to achieve, as societal changes are necessary to increase market appetite for sustainable products and services [34]. This is supported by Verganti [43], who criticizes that new product development efforts are typically overwhelmed by new ideas without consideration of which ones are most valued by society from an environmental standpoint. Sustainability-centric innovation must seamlessly link the environmental tenets society holds onto with business needs to achieve radical innovations valued by society [44]. This is also asserted by Varey [45], who states that for companies to be truly sustainable, responsible marketing needs to focus on not more products and services, but better products and services.

\subsection{Framework to Assess Sustainability in Innovation}

For companies to get this focus right, Humphreys [46] recommends companies to study how sustainability has evolved over the years to be truly successful in driving sustainability-centric innovation. Proposing the triple bottom line (people, planet and profits) criterion for gauging the success of sustainability-centric innovation [47], Savitz emphasizes that sustainability is more than mere environmental initiatives and concludes that sustainability innovations focusing on these three principles constitute the proactive approach to sustainability-centric innovation. Adopting the concept of Sustainability Value Portfolio from Hart S. [48], companies also need to re-evaluate if there exists any overarching vision guiding the activities in the company. Companies need to assess 
if they have progressed through the four stages of sustainability in the Sustainability Value Portfolio, from pollution prevention to product stewardship to clean technology to sustainability vision [48]. It is important to have a balance in all portfolios to meet evolving needs and ensure that companies are not labelled as greenwashing advocates.

According to Forbes [49], 88\% of survey respondents for Futerra by OnePulse would like brands to help consumers be more environmentally friendly and ethical in their daily life. Although consumers think that they can make a difference, they need more help in doing so. Beyond companies' strong advocacy and values in sustainability, consumers demand companies to help them live their values too. In the same survey, $43 \%$ of respondents said that brands make it harder for them to be environmentally friendly and ethical in their daily lives. Brands have a key role to play in terms of innovating sustainably to ensure that consumers can purchase products that are good for the environment and society [49]. Although government policy innovations and consumer behavioral changes are crucial factors to drive sustainability change, the biggest responsibility still falls on companies as economic engines of the future to ensure a sustainable world.

In the next section, we analyze selected companies that have implemented these principles of sustainability which have catapulted them to be market leaders in the field of sustainability-centric innovation. The SWOT method is used to delve deep into the reasons for their successes and to understand the foundational principles behind their sustainable innovation frameworks which are supported by our literature review. The triple bottom line (people, planet, profit) is also used as criterion to assess the sustainability led innovations.

\section{SWOT Analysis-Selected Companies}

\subsection{Adidas}

In Adidas, sustainability is uniquely viewed as a way of life and not just catered to shareholders' expectations. It is seen as a "team sport" where the company believes everyone-employees, consumers and communities-has a responsibility to play in contributing to sustainability, which will lead to lasting brand success for the company. This is similar to the triple bottom line approach. Adidas's sustainability roadmap is closely linked to the United Nation's Sustainability Development Goals (UN SDG) with clear focus and progress tracking of key performances indices (KPIs) in environmental and social sustainability. Their stellar efforts have been strongly recognized, as evidenced by Adidas's consistent listing on the Dow Jones Sustainability Indices (DJSI) yearly since 1999 [50], where they were ranked best in class for their industry for Environmental Policy and Management Systems, Operational Eco-Efficiency and Social Reporting. In 2019, Adidas was also one of the "Global 100 Most Sustainable Corporations in the World" and was recognized in the World Economic Forum in the same year for being a sustainability leader in its industry.

\subsubsection{Strengths}

- End-to-end sustainability strategy permeating product lifecycle and workplace culture

Adidas's sustainability strategy does not merely cover the facet of business operations, but employees are also encouraged to go green with their workplace habits through various incentives and have individual sustainability goals to achieve.

For example, Adidas aims to reduce water consumption per employee by $35 \%$ against their 2008 baseline at their sites, and has also launched a Green Company initiative, which has an additional monetary car bonus to encourage employees to lower their carbon footprints by using public transportation and low-carbon vehicles [51].

In business context, the various aspects of a circular economy-closed product lifecycles, usage of renewable materials and sustainability-focused mindset in all nodes of the supply chain [52] - are covered through the company's roadmap and various initiatives. Environment-wise, Adidas developed the Environmental Footprint Tool (EFT) for internal and external usage to calculate a monetized environmental footprint that accounts for the 
complete value chain from raw material production to product use and disposal. This has helped Adidas identify opportunities to reduce unnecessary water usage, energy consumption and waste at their contract manufacturing sites where they exceeded their targets per Figure 1 from their 2020 Annual Report.

\section{Supply chain: Progress toward 2020 targets}

\begin{tabular}{|c|c|c|c|c|c|}
\hline 2020 Targets $^{1}$ & & 2020 & 2019 & 2018 & 2017 \\
\hline \multirow{2}{*}{ Water } & $\begin{array}{l}20 \% \text { reduction in water consumption at strategic } \\
\text { Tier } 1 \text { supplier facilities }\end{array}$ & $(36 \%)$ & $(29 \%)$ & $(24 \%)$ & $(15 \%)$ \\
\hline & $\begin{array}{l}35 \% \text { reduction in water consumption at strategic } \\
\text { Tier } 2 \text { apparel material supplier facilities }\end{array}$ & $(43 \%)$ & (34\%) & $(27 \%)$ & $(24 \%)$ \\
\hline Energy & $\begin{array}{l}20 \% \text { reduction in energy consumption at strategic } \\
\text { Tier } 1 \text { supplier facilities and strategic Tier } 2 \text { apparel } \\
\text { material supplier facilities }\end{array}$ & $(23 \%)$ & (22\%) & $(15 \%)$ & (7\%) \\
\hline Waste & $\begin{array}{l}20 \% \text { reduction in waste volume at strategic Tier } 1 \\
\text { supplier facilities and strategic Tier } 2 \text { apparel } \\
\text { material supplier facilities }\end{array}$ & $|30 \%|$ & $(30 \%)$ & $(22 \%)$ & $(10 \%)$ \\
\hline
\end{tabular}

1 Table shows aggregated reduction results for all categories lapparel, footwear and accessories and gear). Baseline year 2014. Results show externally verified data for the previous year.

Figure 1. Adidas' Progress in Reducing Unnecessary Water Usage, Energy Consumption and Waste.

Social-wise, Adidas has understood their power to enact positive social change on global communities, through human rights championing initiatives and fighting against modern slavery. Since 1997, Adidas has implemented a comprehensive human rights and labor program and engaged with their contract manufacturers to protect workers' human rights in terms of working hours, health and safety and fair wages. Their commitment in this area has been robust, evidenced by ongoing and external accreditation their social compliance programs by the Fair Labor Association (FLA) and maintaining their seat on the Advisory Council for the Centre for Sports and Human Rights.

The creation of this holistic strategy across each node of the supply chain and by empowering employees to own the sustainability agenda, Adidas has risen to be best in class in the sports industry for embedding sustainability into the core of their business.

- Recognizing environmental sustainability as a "team sport" through partnerships with entrepreneurial and non-governmental organizations (NGOs)

Adidas has understood the value of incubators and partnerships with niche startups and NGOs to pursue breakthrough new product strategies and designs [53]. Such organizations often have been spearheading the creation of entrepreneurial innovation products, which are designed aiming to reduce regulatory registration complexities and reduce adverse ecological and health impacts for the end-user. Through these supply chain collaborations, Adidas has stretched their creative thinking and experimented with new product ideas while driving the sustainability agenda [30].

For example, Adidas has partnered with Parley, an NGO championing protection of our oceans, to create the Ultra Boost shoe series. This was the world's first shoe to be made from marine plastic waste and it brought about a sustainability revolution in the sports and fashion worlds. Working with the constraint of using reclaimed marine plastic waste [50], Adidas designers were challenged to think out of the box and achieved a breakthrough in bringing together three of Adidas's pinnacle running technologies-Boost, Torsion and Continental [54]. In the fashion world, the shoe had a high lifestyle appeal with its sleek design, toned-down color palette in contrast to neon and bright colors typical of performance sneakers, on top of its unrivalled comfort [55]. Together with the sustainability 
hype generated, it is considered as the shoe of choice by prominent celebrities, such as Jessica Alba and Kendall Jenner.

\subsubsection{Weaknesses}

- Sustainability innovations are focused on narrow product range (footwear only)

Adidas's key sustainability product innovations-the Ultra Boost and Futurecraft Loop-are purely footwear, as compared to their biggest competitor Nike. This is due to Adidas's narrow brand portfolio consisting of only the Adidas and Reebok brands, which limits their product offerings in the sportswear and sports accessories sector. On the other hand, Nike has diversified its portfolio through its acquisition of niche brands such as Umbro, a leading football brand, and Hurley, a youth sports lifestyle footwear, apparel and accessories brand [56]. Despite Umbro being sold off in 2012, broadening their portfolio has helped Nike gain competitive advantage over Adidas in growing core competencies to bring about sustainability product innovations across a wider range of products. This is evidenced through Nike leveraging their Flyknit sustainable shoe technology and incorporating it into sports apparel to achieve torso-to-toe innovation, creating the Nike Vapor Kits with AeroSwift Technology for national football players in 2014 [57]. Nike claims that the apparel kit is able to wick sweat from the skin $20 \%$ faster and drying $25 \%$ faster than recent football kits at that time [57]. The texturized yarn used is also made using recycled polyester that is $10 \%$ lighter with $50 \%$ more stretch than current kits of that time. It was also woven using a precision knitting process, which Nike claims produces $60 \%$ less waste than traditional cut-and-sew methods for their Flyknit product range. This example clearly reflects how Nike has leveraged sustainability innovations in their footwear to achieve breakthroughs in another product segment due to robust core competencies across a wide range of side brands.

\subsubsection{Opportunities}

- Empowering the consumer to do more in contributing to social sustainability, besides environmental-wise

Adidas could extend frameworks of their well-established environmental sustainability initiatives and link them to their human rights and modern slavery initiatives to empower consumers to contribute to social sustainability via ethical fashion initiatives. With growing knowledge among consumers regarding manufacturing practices in general, consumers are more willing to spend on products that are ethically manufactured. Dickson [58] and Shen et al. [59] went further to suggest that "consumers who have sufficient knowledge about the workings of the fashion industry are more willing to support and reward ethical business practices through their purchase". Adidas could ride on this trend and carve a unique brand name as a social sustainability advocate. For example, Adidas could leverage on its current Run for the Oceans initiative-instead of doing the same iteration yearly whereby each dollar raised for each kilometer run by the public are used to support ocean plastic reduction initiatives, unique yearly editions could be established to support Adidas's various partnerships with human rights organizations (e.g., Fair Labor Association). The funds could potentially be used to fund targeted trainings and textile worker capacity building initiatives to ensure workers have freedom of speech and are free from debt bondage [60]. This would create a strong sense of social responsibility in consumers which could positively impact their buying behavior [61] and perhaps even convert new consumers to brand-loyal ones-many consumers have reported they would switch to brands that are socially more responsible $[62,63]$.

\subsubsection{Threats}

- Intense competition from peers who are also establishing similar sustainability frameworks as Adidas 
Adidas's competitors-Nike, New Balance and Under Armor-have similar sustainability-centric innovation roadmaps focusing on environmental and social sustainability. There are elements of water, waste and energy reduction in the environmental side, a focus on human rights under the social sustainability umbrella and marketing heavily focused on sustainability-centric product engineering innovations (e.g., Nike's Flyknit, New Balance's Fresh Foam Hierro) across these companies. Even though Adidas is currently leading in this field in the sports industry, it should not rest on its laurels and focus resources on achieving greater progress in the social sustainability side. Based on external critics such as Good on You [64], Adidas should focus on ensuring its contract manufacturing workers are guaranteed living wages. The Foul Play report by the Clean Clothes Campaign and Collectif Ethique sur l'Etiquette highlights the significant gap between sponsorship funds for popular athletes and the share of the final prices of its sports goods which are being paid to these workers. It claims that the latter has dropped 30\% compared to the 1990s, and based on the Asia Floor Wage calculation, most workers are living at the poverty line [65]. Hence, critics have called for concrete and swift steps to tackle this issue and this is an area Adidas could work in to turn a threat into a strength should they become the pioneer in achieving significant progress in this aspect.

\subsection{L'Oréal}

Achieving sustainability in an industry well-known for its heavy use of plastics and chemicals is no mean feat-L'Oréal's effectiveness requires tackling the challenge head on with its aggressive commitments for 2030 in the environment, social and economic space. L'Oréal believes that sustainability innovation is at the core of its business to develop beauty products according to its sustainability program "Sharing Beauty with All" through tackling each stage of a product's development [66].

L'Oréal has shown good performance in its sustainability indices. It was awarded with a triple A score on its efforts to mitigate climate change, protect forests and safeguard water security by Carbon Disclosure Project (CDP), and it obtained an overall score of 81/100 in the environment, social and governance parameters under Refinitiv's Environmental, Social, and Governance (ESG) scoring. If we look deeper into each of the parameters in Refinitiv's ESG scoring, L'Oréal scores high in the social aspect at 87/100, where its strategy contains components of human rights, product responsibility, workforce and community. However, from the environment perspective, it scores $75 / 100$, where the innovation metric is at $37 / 100$.

Assessing L'Oréal's sustainability portfolio, there is great progress in terms of pollution prevention as most material issues in the cosmetics industry revolve around plastic pollution. Hence, efforts are pursued to reduce single-use plastics and plastic waste. This is evident in the move towards designs of larger or refillable packaging, enabling L'Oréal to save 5000 tons of materials between 2017 to 2018. In terms of product stewardship, L'Oréal heavily emphasizes the circular economy and designs for the environment. In 2017, L'Oréal launched $10 \%$ recycled glass and $44 \%$ reduced weight packaging for Vichy's Aqualia Thermal Cream. L'Oréal also launched clean technologies by co-founding a consortium with Carblos to encourage the industrialization of enzymatic bio-recycling technology. In addition, the company partnered with Albea to produce the first carton-based cosmetic tube and collaborated with Quantiz to launch the Sustainable Packaging Initiative for Cosmetics (SPICE) and its sustainability vision L'Oréal For the Future, where the latter outlines the company's sustainability commitments for 2030 which encompass environment, social and economic targets. A deep dive into L'Oréal's sustainability innovation framework and use of quantitative tools is discussed in its SWOT analysis.

\subsubsection{Strengths}

- Integrated end-to-end sustainability strategy

L'Oréal has an integrated end-to-end sustainability strategy. This includes initiatives such as green chemistry and carbon neutral manufacturing powered by renewable energy 
and sustainable packaging innovations. To further improve its sustainability credentials in the innovation space and circular economy, L'Oréal also developed a tool called SPOT (Sustainable Product Optimization Tool) to enable project teams working on innovation to focus on driving sustainability improvements in product launches. To date, there have been great achievements attained: 85\% of new or renovated products in 2019 have an improved environmental or social profile, $54 \%$ of new or renovated products have an improved environmental profile and lower environmental footprint through new formulae, $78 \%$ of new or renovated products have an improved environmental profile due to packaging with a lower environmental footprint. Taking the social aspect into a deeper level, L'Oréal also launched another program called "Solidarity Sourcing" where social inclusion is heavily emphasized and deployed for every type of purchase, benefitting a total of 56,842 women, people with disabilities and disadvantaged communities.

- Well-known strong portfolio of brand

L'Oréal has strong consumer presence, with many renowned brands worldwide. As a beauty giant, it can bring about greater consumer awareness of sustainable consumption, L'Oréal's brands drove key initiatives, such as Biotherm, advocating protection of the oceans through its Mission Blue and Tara Expeditions. Furthermore, in 2018, L'Oréal launched the "Let's recycle in beauty" campaign in France to support collection of cosmetic product packaging which reduces the of waste sent to landfill, closing the loop and promoting a circular economy concept. Personal Care and Beauty Brigade sponsored the initiative, wherein support is provided to raise awareness and educate members of the public, with packaging collection and shipment to their Terra Cycle facility [67].

- $\quad$ Backed by strong research

L'Oréal is backed by strong research. A green chemistry concept is integrated into L'Oréal's innovation model, where chemists invent high-performance and environmentally friendly molecules for its products. Eco-design is guided by a set of indicators capturing the atom economy, waste per kilogram generated in the manufactured product, carbon content and environmental risk generated to provide visibility of the improvement of every product launch. One key example is Pro-Xylene, a sawdust-derived sugar with anti-ageing properties. The chemists continued to explore the sugar chemistry family and subsequently developed the Rhamnose, carrageenan and C-glycosides line [68]. To note, $59 \%$ of products created by L'Oréal in 2019 have an improved environmental profile attributed to the new formula, which uses sustainably sourced materials, or were manufactured using green chemistry.

\subsubsection{Weaknesses}

- The need to innovate due to rapidly changing consumer preference

The cosmetic industry is very dynamic in nature, in that products are required to evolve in a rapid manner due to changing consumer preferences in a short span of time. This means L'Oréal needs to innovate quickly to change the ingredients, packaging or features of its product to keep up with consumer demand. Coupled with high competition, L'Oréal needs to ensure that the products it launches meet sustainability principles covering the environmental, economic and social aspects. For example, many of L'Oréal's products comes in liquid form, requiring a lot of packaging; this would require re-imagining the product in solid form to reduce the need for plastic packaging. This would also require a complete product revamp, which includes its packaging and its supply chain to improve the company's sustainability credentials. With constantly evolving consumer demand, product attributes and supply chains, L'Oréal could be limited by its data recency and successful quantification methods, which may not always be accurate in measuring the real sustainable impact of their products. 


\subsubsection{Opportunities}

- Sustainable products have strong growths projection with opportunity to influence both environmental and social aspects

From a sustainability innovation perspective, there is a strong demand for organic product in the beauty industry, with an extremely attractive Compound Annual Growth Rate (CAGR) of 9.5\% from 2015-2025, according to Capital Mind. With rising consumer awareness of health and safety, there is a rising demand for chemical-free products, which includes a greater understanding of the harmful effects of various ingredients. As a beauty giant, L'Oréal has an opportunity to educate consumers on the ingredients that goes into the products manufactured through campaigns to promote social causes. This is especially so in a non-highly regulated industry on what is defined as organic as well as transparency in ingredients composition. The US cosmetics regulations has not been updated since 1938 , and terminology such as "natural" is not clearly defined without any consistent or quantifiable standards. Beyond formulae, there is also opportunity to further innovate in products, ingredients and packaging space to further improve sustainability credentials. Moreover, there is also opportunity to partner with industry players to influence policy making in the industry and extend partnerships with the community to further social and environmental improvements. This includes partnering with research institutions and academia to further improve the sustainability credentials of its products.

In terms of social sustainability, diversity and inclusion are also key in the agenda, with beauty giants such as L'Oréal ranking in the top 10 of the Refinitiv Diversity and Inclusion Index. There is further opportunity to promote diversity by including models with Down syndrome for L'Oréal. Pioneering models such as Madeline Stuart in the Paris fashion week and Ellie Goldstein for Gucci's mascara have paved ways for normalizing Down syndrome [69]. Organizations can trailblaze and challenge the status quo, which is critical to driving social change.

\subsubsection{Threats}

- Strong competition on sustainability innovation front with challenges osustainable ingredients

With increasing pressure from competition and consumer demands to provide innovative and sustainable beauty solution, L'Oréal needs to introduce sustainable product offerings to stay relevant. In the personal care beauty market, L'Oréal is facing stiff competition from groundbreaking companies such as Lush, with $85 \%$ of its products being vegan and using minimal packaging. Moreover, sustainable plant-based ingredients such as jojoba oil and rosehip oil are facing supply constraints and sourcing challenges. There is also the issue of transparency and traceability, with challenges in tracing ingredients' origin accurately to ensure they are as environmentally and socially sustainable as claimed.

While L'Oréal is a market leader on the sustainability front with clear sustainability vision it desires to achieve by 2030, it needs to be agile in responding to customer needs, demands and trends from a sustainability innovation perspective. L'Oréal has a huge opportunity to develop innovative solutions in sustainable ingredients, packaging and manufacturing through its strong research and development, external partnerships and collaboration with consumers. This would in turn boost its Refinitiv's innovation score under the environment section. It is important to exercise caution from rising competitors, traceability and environmental risks in terms of ingredient sourcing.

\subsection{Johnson \& Johnson (JEJ)}

J\&J is the world's largest healthcare company with sustainability at its core; they believe that the greatest impact can be achieved by leveraging the strength of their people, expertise and partnerships. J\&J's sustainability focus dates back even in early 1970s where it is reflected in their credo that it is their responsibility to "protect environmental and natural resources". J\&J's sustainability roadmap, named Health for Humanity, aims to build a world where healthy people thrive in healthy communities on a healthy planet, 
which is similar to the triple bottom baseline (people, planet, profits) mentioned in the literature review. In addition, similar to Adidas, J\&J aligned the roadmap's deliverables to specific UN SDGs (SDGs 3, 5 and 17, namely good health and well-being, gender equality and global partnerships for sustainable development respectively) [70], in which J\&J has unique expertise, to create a healthier and more equitable world. The strong commitments by J\&J in sustainability-centric innovation has earned the company the Energy Star Partner of the Year Award in 2019 for demonstrating energy-efficient best practices, and a spot on the CDP A List for its efforts to spearhead climate change efforts in 2018 [71].

\subsubsection{Strengths}

- Usage of quantitative tools to clearly govern end-to-end project management process of sustainability-centric product innovations

Echoing L'Oréal's SPOT, J\&J has also developed a similar program and supporting tool named Earthwards and GAIA, since 2009 and 2010, respectively, to achieve one of its goals under its Health for Humanity 2020 Program, where new and existing products representing $20 \%$ of total revenue should achieve in-house recognition for sustainable innovation improvements [72].

Earthwards is a unique program dedicated to empowering employees to design more sustainable products and brainstorm innovative improvements by integrating sustainable design solutions into the product innovation process. Employees are pushed to think critically about the type of materials used, where they are sourced from and what happens to the product after usage. Based on initial responses, product teams then pass each potential product through a lifecycle assessment (LCA) covering the entire product life cycle. It starts from the impact brought about by research and development of materials and products to the end-of-life stage, typically concerning the recyclability of the products and efforts to partner with consumers on product phase-out [73]. From the assessment results, product teams select stages with the highest potential impact to brainstorm focused improvements [73].

J\&J has also expanded Earthwards by creating an Earthwards recognition label to celebrate breakthrough achievements for the most broadly improved products. The company invites external experts to evaluate their products across impact areas of material, water, energy, packaging, waste, social and innovation, and if the product demonstrates significant improvements in at least three of these areas, the recognition is awarded. It is a comprehensive program successfully embedding a sustainable way of life in the J\&J continuous improvement framework, while strengthening corporate culture through recognizing and celebrating breakthrough achievements made by employees, which in turn makes them feel proud and empowered that the work they do makes a difference in reducing environmental footprints.

To support fulfilment of its Health for Humanity goal, Robert Predale, Director of Environmental Product Stewardship at J\&J Consumer Division, developed a patented tool named Global Aquatic Ingredient Assessment (GAIA) [74]. It is a user-friendly tool built to evaluate the environmental impact of product formulations when its ingredients enter the aquatic ecosystem, through measurement of their biodegradability, bioaccumulation profile in certain animal species and toxicities. These three parameters are converted into a weighted score from 0 to 100, wherein 100 represents a highly biodegradable ingredient gentle on the environment. GAIA is also linked to the Earthwards recognition system, wherein a consumer product can achieve significant improvements in one out of the minimum three areas needed should its formulation earn a score of 80 or higher. Hence, using quantitative project management and formulation frameworks, J\&J has accelerated its innovation cycle lead time-in 2010, there were only three Earthwards-recognized products; by 2016, there were 93; and by 2017, more than 290 improvements were made across the different nodes [75]. 


\subsubsection{Weaknesses}

- Expanding scope of partnerships with contract manufacturers within current programs

J\&J's engagement with suppliers is limited to its Sustainability Procurement Program (SPP) and its Supplier Diversity and Inclusion (D\&I) program. While the SPP is moving in the right direction by holding its suppliers accountable for their environmental, human rights and health and safety performances, it is mainly focused on audits with little mention of specific corrective actions or collaborative initiatives undertaken by J\&J to improve supplier performance in these areas based on the audit findings. Based on the positive testimonies of selected suppliers in its 2019 Annual Report, J\&J could model these actions based on the proactive and impactful work achieved with their suppliers in maintenance and improvement of product quality. J\&J has developed tools (Technical Assessments, Supplier Quality Excellence in Execution Tool, Robust Process Framework, Supplier Quality Academy) in partnership with suppliers to support them in managing, measuring and improving product quality. Hence, J\&J could take their SPP program a step further through deeper supplier collaboration to put in place robust frameworks to govern and progress supplier performance.

In addition, J\&J's D\&I program is focused in Australia, Canada, South Africa, America and the United Kingdom, which are mostly developed countries. J\&J could leverage on these established networks and learnings through D\&I initiatives to further expand them into the Asia Pacific (APAC) region. Asia contains the greatest diversity of traditions, races, cultural heritage and political systems (Cooke and Kim, 2018). There is also an added challenge of managing sexual and gender topics in the workplace due to traditional societal perceptions towards women and sexual orientations. Laws on these topics are also not well-enforced and are vague compared to other regions [76]. Therefore, there is a strong business case and opportunity for J\&J to broaden D\&I improvements in APAC.

\subsubsection{Opportunities}

- Expansion of packaging recycling plans to reduce product lifecycle impact

As identified in J\&J's 2019 Annual Report, resources need to be allocated to implement short and long-term actions to commit to its Consumer Health $100 \%$ recyclability commitment through designing for recyclability and investing in recycling infrastructure to address hard-to-recycle formats such as tubes and films. This is a strategic direction to move in, as supported by research. Via statistical analysis [77], consumers were made to select desirable packaging based on a series of attributes and it was found that the top three characteristics were high convenience, package type and sustainability. For the latter, there was a particular focus on how recyclable the packaging was. Glass and bioplastic containers were rated most sustainable, while plastic bags, containers and tubes were rated as least sustainable. This shows that returnability and packaging material are the two key factors consumers use to judge the level of packaging sustainability, according to van Dam [78]. Another interesting finding in this same study is that although plastic was considered least sustainable by consumers, the implementation of a monetary-based return system improved consumer perception of environmental friendliness due to improved recyclability. Hence, J\&J could consider implementation of large-scale return systems globally across a wider range of products-the opportunity is huge, considering that packaging accounts for $40 \%$ of global plastic usage [79].

\subsubsection{Threats}

- $\quad$ Long-term presence of COVID-19 with limited focus on supporting frontline workers globally

While J\&J has made significant progress in rolling out monetary and human resources to support procurement of meals, personal protective equipment (PPE), mental healthcare and trainings for frontline healthcare workers amidst COVID-19, most initiatives and partnerships are concentrated in America. However, with COVID-19 being a global pandemic, 
it has stretched many healthcare systems beyond the supportable level $[80,81]$, with WHO calling out the significantly high physical and mental burdens on frontline workers and pressing for immediate actions to tackle these issues (WHO, 2020). Besides having an increased risk of infection [82], frontline workers have reported symptoms of post-traumatic stress, burnout, depression and anxiety even after a pandemic is over [83]. As COVID-19 is a prolonged crisis, it is vital to safeguard the well-being of frontline workers [84]. There is thus a pressing need and opportunity for J\&J to leverage their networks to partner healthcare organizations in other countries to scale up current resources, which will further broaden and strengthen their sustainability pillar of providing "Better Health for All".

\subsection{Procter \& Gamble (PEG)}

During Earth Week in 2018, P\&G launched its "Ambition 2030", embracing sustainability-centric innovation as a force for good and growth [85]. One of its key focus is "Brands making a positive impact", with $100 \%$ of its key brands aiming to enable and inspire responsible consumption [86]; each of $P \& G$ 's brands has its own sustainable innovation goals to achieve its target by 2030 under the "Brand 2030" campaign. This includes both environmental goals such as reducing emissions as well as proactively collaborating with communities through its sourcing policy, along with efforts toward social causes.

In terms of the sustainability index, P\&G attained an overall score of 73/100 in the Refinitiv ESG score. However, in terms of innovation, P\&G obtained a 99/100 scoring. $P \& G$ 's CDP scores for 2020 were B for both climate and water. It is working with CDP to improve its scores and performance.

Assessing P\&G's sustainability portfolio, there is a focus on pollution prevention through improving existing manufacturing facilities to reduce energy, carbon dioxide emissions, water usage and waste disposal. In its Mehoopany, Pennsylvania, plant, a heat recovery system is used to reclaim energy to power twelve thousand households annually. On product stewardship, $P \& G$ uses the Life Cycle Assessment [87] to comprehensively understand the environmental footprint at every stage of the supply chain, finding opportunities to improve the social and environmental footprints of their products. This has led to breakthrough innovation, ranging from laundry concentrate to water efficient detergent and mops. On the clean technology front, $P \& G$ built sustainable facilities using industry knowledge combined with a proprietary 77-point process to evaluate material sustainability elements of water, materials, systems and lighting. This has resulted in an efficient manufacturing process with a $96.12 \%$ yield [88]. In terms of sustainability vision, a deep dive into the $P \& G$ sustainability innovation space and its usage of quantitative tools is discussed in its SWOT analysis.

\subsubsection{Strengths}

- Clear sustainability vision, program and target for each of its product

$P \& G$ has a clear sustainability vision, rigorous program and target for each of its products. This is unique to $P \& G$, where sustainability innovation is measured and expected at a product level where the norm is typically at a company-wide level. P\&G also takes a scientific approach in delivering sustainable innovation using a Life Cycle Assessment, considering the environmental footprint of a product throughout its life cycle. Taking the example of its leader brand, Pampers, it introduced a program called "7 Acts for Good" with the following integrated goals to achieve by 2030 on its sustainable innovation front. On its raw material front, Pampers aims to innovate towards better diapering solutions with $30 \%$ less diapering materials used per baby over their diapering period with the same dryness performance level. Closing the loop, this product innovation will coincide with launching three recycling facilities to process diapers and wipes by 2021 [89]. In Italy, P\&G has partnered with a healthcare group Angelini to avoid landfill disposal of dirty diapers by upscaling them into plastic bottle caps and cellulose-based clothing materials [90]. From a social aspect, Pampers is leading a partnership with UNICEF to eliminate diseases such as maternal and neonatal tetanus in 25 countries as of March 2019. Beyond Pampers, there are 
many great innovations that $P \& G$ have launched to market which have set the precedence for the consumer goods industry.

- Strong commitment to innovation-sustainability

$P \& G$ has a strong commitment to innovation where it invests heavily in research and development, spending nearly USD 2 billion annually, approximately $50 \%$ more than its closest competitor [91]. This is evident from the numerous recognition and awards obtained on the sustainability front, one example is "2017 Momentum for Change Lighthouse Award", for being the first company to launch a packaging innovation using ocean plastic for its recyclable shampoo bottles. Its innovation of Tide Purclean laundry detergent was recognized as the product of the year in 2018 with credentials such as being made with $100 \%$ renewable energy, plant-based materials and dye-free, with performance as powerful as regular Tide. Considering water as a scarce resource, Swiffer WetJet launched a new variant that saves more than 70 gallons of water per year compared to a normal mop and bucket [86]. To repurpose waste and avoid landfills, P\&G partnered with award-winning HolyGrail innovation which enhances performance at its material sorting and recycling facilities. The impact that $P \& G$ has is huge due to its sheer scale of 300 brands globally and accessibility in more than 180 countries. Its novel approach in integrating sustainable innovation into its brand strategy has led to numerous launches of pioneering sustainable products. It led teams to work cross-functionally towards the same goal of improving the sustainability credentials in each of its products and create better versions than before. With this approach, $P \& G$ remains one of the world's most innovative companies [92].

\subsubsection{Weaknesses}

- More could be done to improve sustainability performance of its products

Despite the award-winning sustainable innovations that $P \& G$ has delivered, more could be done from an environmental and social performance point of view to $P \& G$ 's existing product line, such as its tree-to-toilet pipeline tissue products-Charmin, Bounty and Puffs. All these products are made with 100\% virgin forest, sourced from boreal forests. Not only does this destroy carbon-dense forests on the planet, but it is also robbing indigenous communities their homes and threatening species within the forests [93]. This has earned $P \& G$ an $F$ grade for all of its tissue products, compared to competitors that are switching to recycled content or sustainable alternative fibers which have reduced climate impact. Despite its campaigns "It's Our Home" with announced targets such as "carbon neutrality by 2030", P\&G faced huge criticisms because of its continued use of boreal forests and investments in protection carbon sinks as a way of offsetting their carbon emissions. Moreover, P\&G does not measure its Scope 3 emissions, defined by the Environmental Protection Agency (EPA) as value chain emissions in both upstream and downstream of an organization's activities [94]. It refers to the entire cradle-to-grave lifecycle of a product which encompasses its sourcing, carbon impacts of logging and product usage at home. There needs to be a plan to improve both environmental and social impacts of $P \& G^{\prime}$ s product lines to remain consistent with its sustainable vision.

\subsubsection{Opportunities}

- Customer-focused insights and reframing sustainability challenges as opportunities for sustainability innovation

Brands need to be comfortable in leading customers on sustainability. As famously positioned by Marks \& Spencer's Former CEO, Stuart Rose: "If you wait for customers to tell you that you need to do something, you are too late. Good business leaders should be half a step ahead of what customers want" [95]. This is an opportunity for many companies to focus on consumer insights. P\&G utilized the following insight: " $72 \%$ of people want to be more environmentally conscious at home but more than half don't make sustainable choices as often as they would like, citing barriers including not knowing how $(30 \%)$ and feeling it is too complicated or overwhelming to do so (24\%) [96]". On top of 
providing sustainable products such as Tide Cold Water, P\&G also influences consumer behavior through advertisements, encouraging them to make more sustainable choices at home to empower the next generation. Moreover, sustainability challenges in terms of environmental and social aspects continue to plague our society, and these are areas in which companies can play an active role to tackle these challenges through finding synergies with sustainable innovation.

\subsubsection{Threats}

\section{- Cost of implementing real change and scalability}

The scale of transformation required to implement sustainable change and innovation in a company is huge but must be executed in line with regulatory and consumer pressures. Sustainability innovation promises cost savings in the long term when improvements in products, processes or technology are employed [97]. While companies backed by strong funding can cover the initial cost of innovating sustainably, this is not a luxury for all. Moreover, implementing real change in sustainability goes beyond internal production as well as the cradle-to-grave approach; partnering with communities to ensure social aspect is also considered when sourcing the materials. Beyond research and development, scalability in production remains a challenge. For instance, in $P \& G$, demands for bio-based materials have paved the way for building an infrastructure for manufacturing bio-materials which is not as large, efficient or optimized as synthetic-based products [98]. This remains a threat to most consumer goods companies on a journey towards implementing sustainability innovation in the respective companies.

P\&G has trailblazed on the sustainability innovation front to produce products such as Tide Purclean Laundry Detergent, Head and Shoulders 25\% Plastic Ocean Bottle and Cascade Platinum ActionPacs. This is also contributed to by its rigorous program and targets for each of its products, utilizing scientific tools such as Life Cycle Assessment as a quantification method. However, more can be done in terms of its contentious products such as tissues as well as in terms of full disclosure and accountability towards Scope 3 carbon emissions. Despite cost and scalability threats in implementing sustainability innovation, consumer demands, regulatory pressures and internal sustainability targets should drive P\&G towards sustainable innovation. Moreover, the sheer amount of sustainability challenges presents a huge platform for sustainable innovation and this could be further leveraged through consumer insights.

\section{Key Insights}

Table 1 shows a summary of the Strengths, Weaknesses, Opportunities and Threats (SWOT) in terms of sustainability strategies of selected companies known to be market leaders in their own industries for sustainability-centric innovation.

The SWOT analysis of the selected companies shows similarities and differences that could be derived as key insights across the industry which will guide companies in future sustainability innovation.

Table 1. SWOT summary for selected companies' sustainability strategies.

\begin{tabular}{ll}
\hline \multicolumn{1}{c}{ Strengths } & \multicolumn{1}{c}{ Weakness } \\
\hline $\begin{array}{l}\text { End-to-end sustainability strategy permeating product lifecycle } \\
\text { and workplace culture }\end{array}$ & $\begin{array}{l}\text { Sustainability innovations are focused on narrow product range } \\
\text { (footwear only) }\end{array}$ \\
$\begin{array}{l}\text { Recognizing environmental sustainability as a "team sport" } \\
\text { through partnerships with entrepreneurial and } \\
\text { non-governmental organizations (NGOs) }\end{array}$ & \\
\hline
\end{tabular}

\section{L'Oréal}

Integrated end-to-end sustainability strategy

The need to innovate due to rapidly changing consumer preference

Well-known strong portfolio of brand

Backed by strong research

Johnson \& Johnson (J\&J) 
Table 1. Cont.

\begin{tabular}{lc}
\hline \multicolumn{1}{c}{ Strengths } & \multicolumn{1}{c}{ Procter \& Gamble (P\&G) } \\
\hline $\begin{array}{l}\text { Clear sustainability vision, program and target for each of } \\
\text { its product } \\
\text { Strong commitment to sustainability innovation }\end{array}$ & $\begin{array}{c}\text { More could be done to improve sustainability performance of } \\
\text { its products }\end{array}$ \\
\hline \multicolumn{1}{c}{ Opportunities } & Adidas \\
\hline $\begin{array}{l}\text { Empowering the consumer to do more in contributing to social } \\
\text { sustainability, besides environmental-wise }\end{array}$ & $\begin{array}{l}\text { Intense competition from peers who are also establishing } \\
\text { similar sustainability frameworks as Adidas }\end{array}$ \\
\hline $\begin{array}{l}\text { Sustainable products have strong growths projection with } \\
\text { opportunity to influence both environmental and social aspects }\end{array}$ & $\begin{array}{l}\text { Strong competition on sustainability innovation front with } \\
\text { challenges on sustainable ingredients }\end{array}$ \\
\hline $\begin{array}{l}\text { Expansion of packaging recycling plans to reduce product } \\
\text { lifecycle impact }\end{array}$ & $\begin{array}{l}\text { Long-term presence of COVID-19 with limited focus on } \\
\text { supporting frontline workers globally }\end{array}$ \\
\hline $\begin{array}{l}\text { Customer-focused insights and reframing sustainability } \\
\text { challenges as opportunities for sustainability innovation }\end{array}$ & \begin{tabular}{l} 
Procter \& Gamble (P\&G) \\
\hline
\end{tabular}
\end{tabular}

Figure 2 illustrates how companies can achieve sustainability-centric innovation and bring positive environmental, economic, and social impact. For companies to be successful in sustainability-centric innovation, it is fundamentally necessary for companies to have the following qualities:

- Having genuine intent to improve sustainability of environments and communities;

- Having a sustainability champion mindset: companies should believe in their capabilities to make a difference through leveraging their networks and resources.

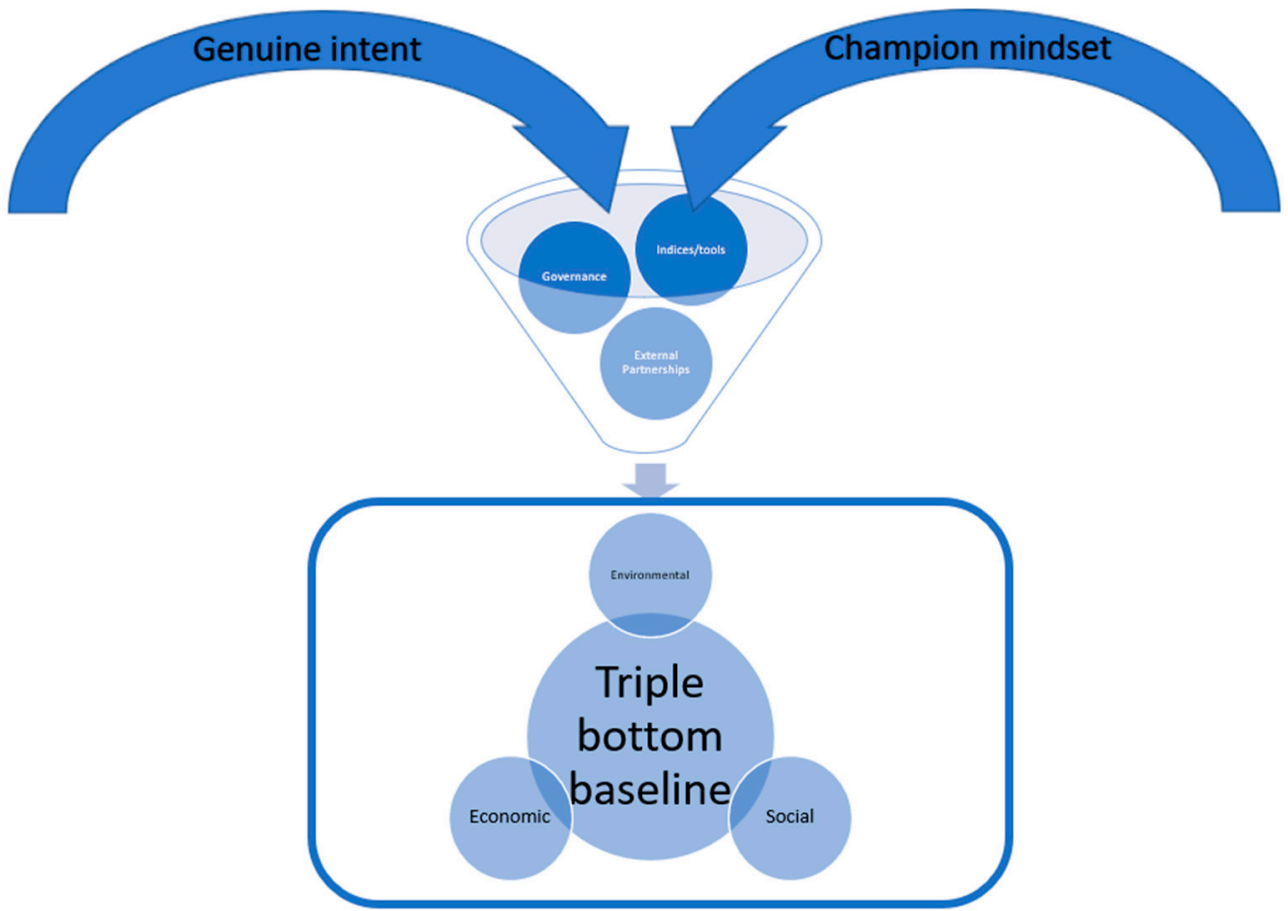

Figure 2. From sustainability-centric innovation to triple bottom baseline principles. 
These qualities should be reflected through:

\section{Governance}

Companies should establish a governance council to craft a sustainability roadmap using the triple bottom baseline principles. A roadmap is crucial to govern a company's sustainability goals and directions. It should address all nodes of its supply chain, end-toend, and encompass the end-user experience to generate high payoffs and build strong consumer relationships. It should have a strong and relatable motif to engage and encourage employees to make sustainability a way of life, in and out of work. Tapping into the collective strength, creativity and capability of a company's employees across all functions is vital to bring innovation to greater heights and ensure long-term success in sustainability-centric innovation.

The roadmap should also be managed by the council, and the council should be accountable for milestone tracking through continuous engagement with stakeholders. The council must be transparent in sustainability reporting when they are invited by external think-tanks to disclose information. A high level of transparency and accountability in the governance structure reflects genuine intent of furthering the sustainability agenda to consumers.

\section{Indices/tools}

For accurate progress and results to track and report, companies should invest in internal talent and research and development (R\&D) to create quantitative tools/indices to manage sustainability projects and innovations end-to-end, with consistently clear direction and progress. Companies can take this a step further by seeking accreditation from external think-tanks to validate the tool's credibility, which will strengthen consumer trust in their sustainability initiatives.

\section{External partnerships}

Finally, companies should be open to investing a significant amount of financial and human resources with strong corporate endorsement, and open to look beyond its internal capabilities to attract talents and build partnerships with specialist organizations. This will help companies to expand its horizon of thinking in terms of sustainability-centric innovation and generate breakthrough solutions to roadblocks faced in sustainability initiatives and even birth out new initiatives, which may be the first of its kind to propel companies to become sustainability leaders in their own field.

Upon studying these global companies leading sustainable innovation performance in their respective industries, there are common themes, approaches and learnings that can be derived.

Sustainability has encouraged companies to undertake a different approach to innovating in the 21st century. It has transformed companies' innovation models to include sustainability parameters and ambitious goals. Take the example of P\&G's "Brand 2030" vision. It sets goals where " $100 \%$ of our leadership brands will inspire responsible consumption", "reduce our use of virgin plastic in packaging by 50\%" and "refill and reuse more bottles" [99]. Research from Harvard Business Review has shown that sustainability is key to organizational success and technological innovations that positively impact the top-line returns and bottom-line costs [100]. It has enabled companies to push the traditional boundaries of what is possible for innovation. This is exemplified by how Adidas has made breakthrough innovation-Ultra Boost, a line of shoes made from marine plastic. Not only is this a novel innovation, but it also helps to raise an awareness of the pressing problem of non-sustainability in our society.

Besides pushing boundaries in innovation, it is imperative that companies embed sustainability into their overarching strategy. A Boston Consulting Group (BCG) report accentuates this importance by encouraging leaders to reimagine corporate strategy to ensure the future of the company, environment and society [101]. This appears in the how businesses optimize environmental, social and financial values through creating differentiation. These differences are embedded into their products and services, grounded 
by reimagined and streamlined business models. This is evident through the P\&G Ambition 2030, which embeds sustainability goals into its brand strategy through its Brand 2030 vision, setting key goals to progress further in the field of sustainability-centric innovation. Ranked as the global leader in corporate sustainability by GlobeScan and the SustainAbility compiled annual survey, Unilever started their journey back in 2011 when the Unilever Sustainable Living Plan was first launched, and their work changed the world. This was observed through the impacts made from empowering women, supporting sustainable farming, improving health and protecting forests. Over the span of 9 years, agriculture that is sustainably sourced increased tremendously from $14 \%$ to $62 \%$ [102]. However, Unilever acknowledges that there is more to do and has progressively challenged themselves to more stringent and relevant targets along the way, recently launching a new set of measures and commitments in June 2020. These measures include reaching net zero emissions by 2039 by setting up a system for suppliers to declare the carbon footprint of their goods and services in every invoice. Embedding sustainability closely into a company's corporate strategy, close tracking of progress and continuously challenging one's ambitions are signs of companies showing great leadership in the sustainability space.

It is not enough to merely consider sustainability-centric innovation in one aspect of the value chain; it is imperative for it to be integrated end-to-end to generate even greater payoffs and better manage risks [103]. Tackling sustainability challenges in silo only through substitution efforts may lead to rising financial, social and environmental costs that may not be sustainable in the long term. All the above-mentioned companies have re-thought their supply chain end-to-end, from sourcing all the way to how the consumers interact with and dispose of their products, and this has contributed to their sustained success in the realm of sustainability-centric innovation.

To further enhance companies' performance and gain public trust, it is important to employ relevant tools to enhance transparency and visibility [103]. L'Oréal developed a quantitative tool SPOT to quantify its operational impacts at each value chain to understand its current baseline, innovation and improvement impacts and provide transparency in measurements to stakeholders. There are other relevant tools that are typically used and effectively provide visibility such as life cycle assessments [104], and carbon and energy footprint analysis to understand one's impact. This gives confidence to the public that companies are launching products that are better versions than before, which benefit environments and societies.

Beyond internal focus, these companies have acknowledged the fact that they are not able to tackle challenges and achieve great innovations alone. Support is needed from external partners to further their performance and progress, to unlock new potential and achieve greater heights [103]. The case studies have shown that sustainability is responsible for driving technological and organizational innovations to yield bottom- and top-line returns. Due to added constraints to ensure processes are environmentally friendly, this helps companies maximize their inputs (especially in manufacturing), and the cost savings in turn enable companies to explore other innovation ideas such as creating new businesses or better products to capture market share [105].

Most importantly, sustainability-centric innovation has enabled employees of these companies to see the entire value chain end-to-end and improve cross-functional understanding. When looking for environmental efficiencies, thinking beyond a function's existing domain, partners and overall procedures will become second nature to employees, nurturing a working environment where ideation becomes valuable and comprehensive.

\section{Conclusions}

It is imperative in the current evolution of business that new products and innovations will be the key drivers for growth for any organization. With the onset of COVID-19, it is also clear from the emerging trends that consumers are tending towards sustainability, whether in the form of changes in diet to vegetarian or the use of renewable sources of packaging. From the above two, it follows that unless organizations stay focused on embedding 
sustainability concepts in their innovations that are used to attract consumers and grow the business, they will perish. Companies must truly understand what consumers want and need, inspire, inform, build trust and continue to innovate and invest in sustainability.

This is also supported by findings from BCG's Investor Pulse Check, where 51\% of investors considered it important to pursue ESG considerations in their investment strategy [106]. This forces companies to rethink their sustainability strategies to secure finances in the future. Globally, coalitions, partnerships and funding are established to achieve the United Nations Sustainable Development Goals (SDG), which are a set of 17 interlinked goals designed to achieve a better and sustainable future for all. Companies that are willing to step up to this could secure funding from organizations, such as Google Global Impact Awards and Bloomberg Philanthropy, and reduce costs through waste hierarchy principles, where a cradle-to-grave approach is potentially used to find innovative use of recycled products.

Sustainability innovation is a powerful framework promoting penetration of new customer and market segments that add positive value to a company's global capital. Innovations provide a direct and quick signal to the consumers that their intrinsic concerns are being addressed and that the organization whose products they consume resonate with their thought processes, thereby promoting mutual appreciation and business growth. Consumer preferences are changing and there is a need to incorporate sustainability elements into products. While fixing the past will take time and energy, getting sustainable innovations right the first time serves a greater purpose. All leading companies that have followed suit are starting to see the success in a subtle way, and that is the essence of this change. To stay relevant, agile and competitive in the current evolution of business, it is crucial for companies to put sustainability-centric innovation at the heart of business operations and culture.

Despite the strong demand for sustainability in products and innovation by consumers, there is a difference between consumer perception and purchases. A positive consumer perception does not necessarily translate into a consumer purchase. According to Halverson, consumer perception refers to what consumers think about the products or services of an organization [10]. This could be defined as a consumer's levels of trust, awareness and effectiveness in differentiating one product from another. According to Stokes, consumers have positive perceptions towards green advertising if there is no potentially deceptive information [14]. Once deception is identified by consumers, this would leave an indelible and negative impact on a company's reputation and integrity. Therefore, companies should communicate their sustainability claims about product innovation, practices and accolades only if they are genuine. Although consumers perceive companies focused on sustainably produced products to be better than those not, according to a Harvard Business Review, only $26 \%$ do purchase those sustainable products [9]. This socially responsible and ethical decision to purchase products that bring positive change and reduce harmful effects on environmental and social aspects is referred to as green purchase behavior [107]. A study from Jong, Harkink and Berth shows that the green purchases of consumers increase only when companies demonstrate a real and genuine interest in the protection of the environment [108]. In order to enhance consumer perception and green purchasing behavior, a company should be genuine in its efforts to improve the ESG factors in its end-to-end value chain and sustainable innovation. This continued effort would also enable a more cost-competitive sustainable option for consumers to purchase. Hence, beyond leveraging the sustainability concept to improve brand reputations, operational efficiency and lower costs [8], companies also need to communicate regularly to connect with consumers on a brand's purpose, consistently showing benefits of sustainable options compared to traditional ones and ensuring that sustainability is an irresistible option [9].

Quantitative methodologies are also important, as observed from the case studies. These serve as guiding principles to assess the ESG impact of products throughout product lifecycles. With this baseline in mind, it helps companies to understand materiality, and the results also serve as a benchmark to further improve sustainability credentials in 
their products and supply chains. Companies that have used such methodologies to guide their innovation processes have been able to clearly quantify the environmental, social and economic impacts of their products. Beyond that, the knowledge of such methodologies also increases awareness among consumers of the sustainability topic, leading to increased marketability and profitability of sustainability-marketed products. Internally, sustainability-centric innovation grounded by such methodologies has shown to significantly cut expenses and improve operating profitability, which eventually benefits a company's overall financials.

Given the strong case for sustainability-centric innovation as illustrated by the case studies-benefits of high business competitiveness, increased profitability and strong brand reputations internally and externally-the concluding recommendation is for companies that have not incorporated sustainability into their business operations to take action now and tap into the synergistic relationship between sustainability and innovation through the creation of a roadmap governed by a sustainability council. This should be supported by robust quantitative tools, strategic partnerships with external partners and development capabilities of employees who are committed to driving the sustainability-centric innovation agenda. Should companies get this structure right, and with the presence of such characteristics in their business operations, they will be able to "learn, adapt and lead change" [109].

Author Contributions: Conceptualization, P.J. and M.C.C.; methodology, P.J., M.C.C., F.F. and M.P.S.; software, P.J., M.C.C., F.F. and M.P.S.; validation, P.J., M.C.C., F.F. and M.P.S.; formal analysis, P.J., M.C.C., F.F. and M.P.S.; investigation, P.J., M.C.C., F.F. and M.P.S.; resources, P.J. and M.C.C.; data curation, F.F. and M.P.S.; writing-original draft preparation, P.J., M.C.C., F.F. and M.P.S.; writing - review and editing, P.J., M.C.C., F.F. and M.P.S.; visualization, F.F. and M.P.S.; supervision, P.J., M.C.C., F.F. and M.P.S.; project administration, P.J. and M.C.C.; funding acquisition, P.J. and M.C.C. All authors have read and agreed to the published version of the manuscript.

Funding: This research was funded by NUS Academic Research Fund, grant number R-726-000-008-646. Institutional Review Board Statement: Not applicable.

Informed Consent Statement: Not applicable.

Acknowledgments: The authors would like to thank the editor and two anonymous reviewers for their valuable comments and suggestions that helped improve this paper.

Conflicts of Interest: The authors declare no conflict of interest.

\section{References}

1. Whelan, T.; Fink, C. The comprehensive business case for sustainability. Harv. Bus. Rev. 2016, $21,2012$.

2. Supply Chain Asia. The Importance of Sustainability in Innovation: The Impact of Quantitative Tool to Measure Sustainability Progress and Capabilities. Available online: https://supplychainasia.org/importance-sustainability-innovation/ (accessed on 23 January 2020).

3. The Guardian. Most Ambitious US Law to Tackle Single-Use Plastics. Available online: https://www.theguardian.com/usnews/2019/sep/13/california-plastics-legislation-single-use (accessed on 13 September 2019).

4. News European Parliament. Protecting the Rights of Indigenous People. Available online: https://www.europarl.europa.eu/ news/en/agenda/briefing/2020-01-29/6/protecting-the-rights-of-indigenous-people (accessed on 28 January 2020).

5. Deloitte. Millennials Want Business to Shift Its Purpose. Available online: https://www2.deloitte.com/us/en/pages/aboutdeloitte/articles/millennials-shifting-business-purpose (accessed on 23 January 2021).

6. Rachelson, D. A Brief History of the Modern Sustainability Movement. Available online: https://www.rubiconglobal.com/blog/ brief-history-sustainability-movement/ (accessed on 19 December 2018).

7. Kuhl, M.R.; Da Cunha, J.C.; Maçaneiro, M.B.; Cunha, S.K. Relationship between innovation and sustainable performance. Int. J. Innov. Manag. 2016, 20, 1650047. [CrossRef]

8. McKinsey Sustainability. The Business of Sustainability. Available online: https://www.mckinsey.com/business-functions/ sustainability / our-insights/the-business-of-sustainability-mckinsey-global-survey-results (accessed on 1 October 2011).

9. White, K.; Hardisty, D.J.; Habib, R. The elusive green consumer. Harv. Bus. Rev. 2019, 11, 124-133.

10. Halverson, R. Consumer Perceptions of Greenwashing: Understanding Awareness, Trust, and Effectiveness. Bachelor's Thesis, University of Colorado Boulder, Boulder, CO, USA, 2018. 
11. Pinsent Masons. Greenwashing under Regulatory Scrutiny. Available online: https://www.pinsentmasons.com/out-law/ analysis/greenwashing-under-regulatory-scrutiny (accessed on 26 January 2021).

12. Parguel, B.; Benoit-Moreau, F.; Russell, C.A. Can evoking nature in advertising mislead consumers? The power of 'executional greenwashing'. Int. J. Advert. 2015, 34, 107-134. [CrossRef]

13. Krafft, J.; Saito, R. Greenwashing an Experimental Study about the Effects of Misleading and Deceptive Environmental Claims in Advertising. Bachelor's Thesis, University of Gothenburg, Gothenburg, Sweden, 2014.

14. Stokes, S.A. Deception in Environmental Advertising: Consumers' Reactions to Greenwashing. Ph.D. Thesis, Kansas State University, Manhattan, KS, USA, 2009.

15. Cleff, T.; Rennings, K. Are there any first-mover advantages for pioneering firms?: Lead market orientated business strategies for environmental innovation. Eur. J. Innov. Manag. 2012, 15, 491-513. [CrossRef]

16. Kerin, R.A.; Varadarajan, P.R.; Peterson, R.A. First-mover advantage: A synthesis, conceptual framework, and research propositions. J. Mark. 1992, 56, 33-52. [CrossRef]

17. Kalyanaram, G.; Robinson, W.T.; Urban, G.L. Order of market entry: Established empirical generalizations, emerging empirical generalizations, and future research. Mark. Sci. 1995, 14 (Suppl. 3), G212-G221. [CrossRef]

18. Lieberman, M.B.; Montgomery, D.B. First-mover (dis) advantages: Retrospective and link with the resource-based view. Strateg. Manag. J. 1998, 19, 1111-1125. [CrossRef]

19. Lieberman, M.B.; Montgomery, D.B. First-mover advantages. Strateg. Manag. J. 1988, 9 (Suppl. 1), 41-58. [CrossRef]

20. Jakopin, N.M.; Klein, A. First-mover and incumbency advantages in mobile telecommunications. J. Bus. Res. 2012, 65, 362-370. [CrossRef]

21. Lee, S.K.; Jang, S. Early mover or late mover advantage for hotels? J. Hosp. Tour. Res. 2017, 41, 23-40. [CrossRef]

22. Zhao, Y.L.; Song, M.; Parry, M.E. A Comparative Study of Pioneer Entry Decisions in the United States and China. J. Prod. Innov. Manag. 2014, 31, 987-1003. [CrossRef]

23. Zhang, H.; Song, M. Do first-movers in marketing sustainable products enjoy sustainable advantages? A seven-country comparative study. Sustainability 2020, 12, 450. [CrossRef]

24. NCBI. Biobased Industrial Products: Priorities for Research and Commercialization. Available online: https://www.ncbi.nlm.nih gov/books/NBK232955/ (accessed on 3 June 2021).

25. D'Adamo, I.; Falcone, P.M.; Imbert, E.; Morone, P. A Socio-economic Indicator for EoL Strategies for Bio-based Products. Ecol. Econ. 2020, 178, 106794. [CrossRef]

26. Head \& Shoulders. The World's First Recyclable Shampoo Bottle Made from Beach Plastic. Available online: https:// headandshoulders.com/en-us/whats-new/shampoo-bottles-made-from-recycled-plastic (accessed on 3 June 2021).

27. Schmitz, A. Sustainability, Innovation, and Entrepreneurship; Saylor Academy: Washington, DC, USA, 2012.

28. Ivasciuc, I.-S.; Epuran, G. A Marketing approach on how continuous processes improvement can contribute to hotel business Organic Growth. Bull. Transilv. Univ. Brasov. Econ. Sci. Ser. V 2015, 8, 185.

29. Defining Sustainability Innovation. Available online: https://saylordotorg.github.io/text_sustainability-innovation-andentrepreneurship/s06-02-defining-sustainability-innova.html\#: \{\}:text=Sustainability\%20innovation\%20is\%20about\%20 defining, \%2C\%20human \%20health\%2C\%20and \%20communities (accessed on 3 June 2021).

30. Forbes Business Council; Rafi, T. Council Post: Why Corporate Strategies Should Be Focused on Sustainability. Available online: https: / /www.forbes.com/sites/forbesbusinesscouncil/2021/02/10/why-corporate-strategies-should-be-focused-onsustainability /?sh=5c1e0a2b7e9f (accessed on 8 February 2021).

31. Dyck, B.; Silvestre, B.S. Enhancing socio-ecological value creation through sustainable innovation 2.0: Moving away from maximizing financial value capture. J. Clean. Prod. 2018, 171, 1593-1604. [CrossRef]

32. Kotler, P. Reinventing marketing to manage the environmental imperative. J. Mark. 2011, 75, 132-135. [CrossRef]

33. Schaltegger, S.; Lüdeke-Freund, F.; Hansen, E.G. Business models for sustainability: A co-evolutionary analysis of sustainable entrepreneurship, innovation, and transformation. Organ. Environ. 2016, 29, 264-289. [CrossRef]

34. Charter, M.; Clark, T. Sustainable Innovation: Key Conclusions from Sustainable Innovation Conferences 2003-2006 Organised by the Centre for Sustainable Design; The Centre for Sustainable Design, University College for the Creative Arts: Farnham, UK, 2007.

35. Hansen, E.G.; Grosse-Dunker, F.; Reichwald, R. Sustainability innovation cube-A framework to evaluate sustainability-oriented innovations. Int. J. Innov. Manag. 2009, 13, 683-713. [CrossRef]

36. Kim, H.; Lee, C.W. The effects of customer perception and participation in sustainable supply chain management: A smartphone industry study. Sustainability 2018, 10, 2271. [CrossRef]

37. Chladek, N. The Importance of Sustainability in Business: HBS Online. Available online: https://online.hbs.edu/blog/post/ business-sustainability-strategies (accessed on 6 November 2019).

38. Tezer, A.; Bodur, H.O. The greenconsumption effect: How using green products improves consumption experience. J. Consum. Res. 2020, 47, 25-39. [CrossRef]

39. Grant, A.M.; Gino, F. A little thanks goes a long way: Explaining why gratitude expressions motivate prosocial behavior. J. Personal. Soc. Psychol. 2010, 98, 946. [CrossRef]

40. Geradts, T.H.; Bocken, N.M. Driving sustainability-oriented innovation. MIT Sloan Manag. Rev. 2019, 60, 1.

41. Weiss, A.S.; De Macedo Higgins Joyce, V.; Harlow, S.; Alves, R.C. Innovation and Sustainability: A Relationship Examined Among Latin American Entrepreneurial News Organizations. Cuadernos. Info 2018, 87-100. 
42. Day, J. 3 Reasons Why Sustainability \& Innovation are Related. Available online: https://ideascale.com/sustainability-andinnovation-are-related/ (accessed on 15 February 2017).

43. Verganti, R. The innovative power of criticism. Harv. Bus. Rev. 2016, 94, 18.

44. Boons, F.; Wagner, M. Assessing the relationship between economic and ecological performance: Distinguishing system levels and the role of innovation. Ecol. Econ. 2009, 68, 1908-1914. [CrossRef]

45. Varey, R.J. The marketing future beyond the limits of growth. J. Macromarketing 2012, 32, 424-433. [CrossRef]

46. Humphreys, A. How is sustainability structured? The discursive life of environmentalism. J. Macromarketing 2014, 34, $265-281$. [CrossRef]

47. Savitz, A. The Triple Bottom Line: How Today's Best-Run Companies Are Achieving Economic, Social and Environmental Success-And How You Can Too; John Wiley \& Sons: San Francisco, CA, USA, 2013.

48. Hart, S.L. Beyond greening: Strategies for a sustainable world. Harv. Bus. Rev. 1997, 75, 66-77.

49. Townsend, S. 88\% of Consumers Want You to Help Them Make a Difference. Forbes. Available online: https://www.forbes.com/ sites/solitairetownsend/2018/11/21/ consumers-want-you-to-help-them-make-a-difference/?sh=19d044316954 (accessed on 21 November 2018).

50. Adidas-Group. Top Positions Achieved Again: Adidas in the Dow Jones Sustainability Indices for 20 Years. Available online: https:/ / www.adidas-group.com/en/media/news-archive/press-releases/2019/adidas-dow-jones-sustainability-indices20-years/ (accessed on 16 September 2019).

51. Adidas-Group. Adidas Group's Environmental Approach. Available online: https://www.adidas-group.com/en/sustainability/ managing-sustainability/environmental-approach/\#/unser-ansatz/ (accessed on 3 June 2021).

52. Versnellingshuis Nederland Circulair! What Is the Definition of a Circular Economy? Available online: https://kenniskaarten. hetgroenebrein.nl/en/knowledge-map-circular-economy/what-is-the-definition-a-circular-economy/ (accessed on 3 June 2021).

53. Eagar, R.; Webster, P.; Kilefors, P.; af Sandeberg, I. The next generation of corporate incubators. Available online: https: //www.adlittle.com/en/insights/prism/the-next-generation-of-corporate-incubators (accessed on 3 June 2021).

54. News.adidas. Adidas Works with Thousands of Runners to Create the Revolutionary Adidas Ultraboost 19-A New Shoe For A New Sport. Available online: https://news.adidas.com/running/adidas-works-with-thousands-of-runners-to-create-therevolutionary-adidas-ultraboost-19---a-new-shoe/s/e52fc7af-1c69-4421-a294-2f79d2a1113e (accessed on 11 December 2018).

55. Highsnobiety. The Story of Ultra Boost. Available online: https:/ /www.highsnobiety.com/p/the-story-of-adidas-ultra-boost/ (accessed on 2 December 2018).

56. Nike, Inc. A Growth Company. Available online: https://media.corporate-ir.net/media_files/IROL/10/100529/nike-gs09/ docs / nike-growth-story.pdf (accessed on 3 June 2021).

57. Nike News. Nike Vapor Kits with AeroSwift Technology Anchor Advanced Football Performance System. Available online: https:/ / news.nike.com/news/2016-football-vapor-kit-aeroswift (accessed on 16 March 2016).

58. Dickson, M.A. Personal values, beliefs, knowledge, and attitudes relating to intentions to purchase apparel from socially responsible businesses. Cloth. Text. Res. J. 2000, 18, 19-30. [CrossRef]

59. Shen, B.; Wang, Y.; Lo, C.K.; Shum, M. The impact of ethical fashion on consumer purchase behavior. J. Fash. Mark. Manag. An. Int. J. 2012, 16, 234-245. [CrossRef]

60. Adidas-Group. Human Rights. Available online: https://www.adidas-group.com/en/sustainability/managing-sustainability/ human-rights/\#/uk-modern-slavery-act/ (accessed on 3 June 2021).

61. Pookulangara, S.; Shephard, A.; Mestres, J. University community's perception of sweatshops: A mixed method data collection. Int. J. Consum. Stud. 2011, 35, 476-483. [CrossRef]

62. Smith, G.; Stodghill, R. Are good causes good marketing. Bus. Week 1994, 21, 64-66.

63. Meryl, D. The Champion of Corporate Social Responsibility. Bus. Soc. Rev. 1990, 70, 40-43.

64. How Ethical Is Adidas? Available online: https://goodonyou.eco/adidas-ethical/ (accessed on 9 December 2020).

65. Adidas and Nike Pay Record-Breaking Amounts to Footballers, But Deny Decent Wages to Women Stitching Their Shirts. Available online: https:/ / cleanclothes.org/news/2018/06/11/adidas-and-nike-pay-record-breaking-amounts-to-footballersbut-deny-decent-wages-to-women-stitching-their-shirts (accessed on 11 June 2018).

66. Fast Company. How L'Oréal Is Turning Itself into A Sustainability Leader. Available online: https://www.fastcompany.com/30 69080/how-loreal-is-turning-itself-into-a-sustainability-leader (accessed on 23 March 2017).

67. Prnewswire. L'Oreal's Garnier Brand Announces Exclusive Partnership with TerraCycle. Available online: https://www. prnewswire.com/news-releases/loreals-garnier-brand-announces-exclusive-partnership-with-terracycle-119585849.html (accessed on 11 April 2011).

68. L'Oreal. A Sustainable Purchasing Policy. Available online: https://www.loreal.com/en/articles/a-sustainable-purchasingpolicy/ (accessed on 3 June 2021).

69. Insider. Gucci Beauty's Newest Campaign Stars Ellie Goldstein, an 18-Year-Old Model with Down Syndrome. Available online: https:/ / www.insider.com/down-syndrome-model-ellie-goldstein-stars-in-gucci-campaign-2020-7 (accessed on 1 July 2020).

70. JNJ. Our 2030 Promise a Giant Leap towards a World Where a Healthy Mind, Body, and Environment Is within Reach for Everyone, Everywhere. Available online: https://www.jnj.com/_document?id=00000159-6a9a-d7d5-abdd-eabf33e30000 (accessed on 3 June 2021). 
71. JNJ. The Green Graph: 8 Innovative Ways Johnson \& Johnson Is Helping the Environment. Available online: https:/ www.jnj. com/caring-and-giving/8-innovative-ways-johnson-johnson-is-helping-the-environment (accessed on 21 April 2019).

72. JNJ. Health for Humanity 2020 Goals. Available online: https://www.jnj.com/_document/johnson-johnson-health-forhumanity-2020-goals?id=0000015c-adde-d4cb-a5fd-efdef8110000 (accessed on 3 June 2021).

73. JNJ. Product Stewardship/Earthwards ${ }^{\circledR}$. Available online: https://www.jnj.com/global-environmental-health/productstewardship-earthwards (accessed on 3 June 2021).

74. JNJ. This Johnson \& Johnson Patent Holder Is Helping to Save the Planet. Available online: https://www.jnj.com/innovation/ this-johnson-johnson-patent-holder-is-helping-save-the-planet (accessed on 25 September 2017).

75. JNJ. Earthwards ${ }^{\circledR}:$ The Unique Johnson \& Johnson Program That's Helping to Create a More Sustainable World. Available online: https:/ / www.jnj.com/innovation/earthwards-a-johnson-and-johnson-program-helping-create-a-more-sustainableworld (accessed on 4 July 2017).

76. CfP: Minority in Asia Special Issue. Available online: https://www.springer.com/journal/10490/updates/17843616 (accessed on 3 June 2021).

77. van den Elzen, J. Consumers' Perception Regarding Sustainable Packaging. Bachelor's Thesis, Wageningen University, Wageningen, The Netherlands, 2016.

78. van Dam, Y.K. Environmental assessment of packaging: The consumer point of view. Environ. Manag. 1996, 20, 607-614. [CrossRef] [PubMed]

79. Chen, Y.; Awasthi, A.K.; Wei, F.; Tan, Q.; Li, J. Single-use plastics: Production, usage, disposal, and adverse impacts. Sci. Total Environ. 2020, 752, 141772. [CrossRef] [PubMed]

80. Xie, J.; Tong, Z.; Guan, X.; Du, B.; Qiu, H.; Slutsky, A.S. Critical care crisis and some recommendations during the COVID-19 epidemic in China. Intensive Care Med. 2020, 46, 837-840. [CrossRef] [PubMed]

81. Armocida, B.; Formenti, B.; Ussai, S.; Palestra, F.; Missoni, E. The Italian health system and the COVID-19 challenge. Lancet Public Health 2020, 5, e253. [CrossRef]

82. Xiao, J.; Fang, M.; Chen, Q.; He, B. SARS, MERS and COVID-19 among healthcare workers: A narrative review. J. Infect. Public Health 2020, 13, 843-848. [CrossRef]

83. Park, J.-S.; Lee, E.-H.; Park, N.-R.; Choi, Y.H. Mental health of nurses working at a government-designated hospital during a MERS-CoV outbreak: A cross-sectional study. Arch. Psychiatr. Nurs. 2018, 32, 2-6. [CrossRef] [PubMed]

84. Muller, R.A.E.; Stensland, R.S.Ø.; van de Velde, R.S. The mental health impact of the covid-19 pandemic on healthcare workers, and interventions to help them: A rapid systematic review. Psychiatry Res. 2020, 293, 113441. [CrossRef] [PubMed]

85. The Genius Works. P\&G's Ambition 2030 ... Embracing Sustainable Innovation as "a Force for a Good and a Force for Growth". Available online: https: / www.thegeniusworks.com/2018/06/pgs-ambition-2030-embracing-sustainable-innovation-as-a-forcefor-a-good-and-a-force-for-growth/ (accessed on 14 June 2018).

86. Procter and Gamble. Available online: https:/ / en-ae.pg.com/environmental-sustainability/ (accessed on 3 June 2021).

87. Agarwal, R.; Thiel, M. P\&G: Providing sustainable innovative products through LCA worldwide. South Asian J. Bus. Manag. Cases 2013, 2, 85-96.

88. P\&G Designed to Innovate ... Sustainably. Available online: https://legacymt.pg.com/pgcom-en-us/downloads/sustainability/ reports/PG_2008_Sustainability_Overview.pdf (accessed on 3 June 2021).

89. Sustainablebrands. P\&G Brands Aim to Expand Leadership in Responsible Consumption. Available online: https: // sustainablebrands.com/read/behavior-change/p-g-brands-aim-to-expand-leadership-in-responsible-consumption (accessed on 3 June 2021).

90. Innovation Monitor: P\&G Pursues Sustainable Diapers. Available online: https:/ /strategyonline.ca/2019/07/16/innovationmonitor-pg-seeks-to-make-diapers-more-sustainable/ (accessed on 16 July 2019).

91. Brown, B.; Anthony, S.D. How P\&G tripled its innovation success rate. Harv. Bus. Rev. 2011, 89, 64-72.

92. Forbes. The World's Most Innovative Companies. Available online: https://www.forbes.com/innovative-companies/list/\#tab: rank_header:innovationPremium_search:pr_region:North\%20America (accessed on 3 June 2021).

93. P\&G, You Can't Outsource Sustainability. Available online: https://www.nrdc.org/experts/shelley-vinyard/pg-you-cantoutsource-sustainability (accessed on 16 July 2020).

94. EPA Center for Corporate Climate Leadership. Available online: https://www.epa.gov/climateleadership/scope-3-inventoryguidance\#: $\{$ \}:text=Scope $\% 203 \% 20$ emissions $\% 20$ are $\% 20$ the,impacts $\% 20 \mathrm{in} \% 20 \mathrm{its} \% 20 \mathrm{value} \% 20 \mathrm{chain} . \&$ text=Scope $\% 203 \% 20 \mathrm{emissions} \%$ 2C\%20also\%20referred, an\%20organization \T1 \textquoterights\%20total\%20GHG\%20emissions (accessed on 3 June 2021).

95. Sherwin, C. Unlocking the One Trillion-Dollar Sustainable Innovation Opportunity. Available online: https://innovationmanagement. se/2017/01/12/sustainable-innovation-opportunity/ (accessed on 12 January 2017).

96. Campaignasia. P\&G Campaign Asks Consumers to Get Sustainable. Available online: https://www.campaignasia.com/video/ pg-campaign-asks-consumers-to-get-sustainable/469019\#: \{\}:text=So\%2C\%20over\%20the\%20past $\% 20 \mathrm{few}$, which $\% 20$ can $\% 20$ clean\%20dishes\%20without (accessed on 18 April 2021).

97. Accenture. Delivering on the Promise of Sustainability. Available online: https://www.accenture.com/_acnmedia/PDF-150/ Accenture-Delivering-on-the-Promise-of-Sustainability.pdf (accessed on 3 June 2021).

98. Mischel, F.; Synbiobeta. The Challenges of Big Green: Scaling Sustainability at Procter \& Gamble. Available online: https: //synbiobeta.com/the-challenges-of-big-green-scaling-sustainability-at-procter-gamble/ (accessed on 18 September 2018). 
99. P\&G. Environmental Sustainability. Available online: https://us.pg.com/environmental-sustainability/ (accessed on 3 June 2021)

100. Nidumolu, R.; Prahalad, C.K.; Rangaswami, M.R. Why sustainability is now the key driver of innovation. Harv. Bus. Rev. 2009, $87,56-64$.

101. Welcome to the Young-Reeves Family Adventures. Available online: https://youngreevesadventures.com/2020/07/ (accessed on 3 June 2021).

102. Globescan. The 2020 GlobeScan/SustainAbility Leaders Survey / Report \& Webinar. Available online: https:/ / globescan.com/20 20-sustainability-leaders-report/ (accessed on 12 August 2020).

103. Lee, H.L. Don't tweak your supply chain-rethink it end to end. Harv. Bus. Rev. 2010, 88, 62-69.

104. Towards a Life Cycle Sustainability Assessment. Available online: https://www.lifecycleinitiative.org/wp-content/uploads/20 12/12/2011\%20-\%20Towards\%20LCSA.pdf (accessed on 3 June 2021).

105. Deloitte. Sustainability for Consumer Business Companies. Available online: https://www2.deloitte.com/content/dam/Deloitte/ global/Documents/Consumer-Business/dttl_cb_Sustainability_Global\%20CB\%20POV.pdf (accessed on 11 August 2020).

106. Boston Consolting Group. ESG Commitments Are Here to Stay. Available online: https://www.bcg.com/publications/2020/esgcommitments-are-here-to-stay (accessed on 23 June 2020).

107. Chan, R.Y. Determinants of Chinese consumers' green purchase behavior. Psychol. Mark. 2001, 18, 389-413. [CrossRef]

108. de Jong, M.D.; Harkink, K.M.; Barth, S. Making green stuff? Effects of corporate greenwashing on consumers. J. Bus. Tech. Commun. 2018, 32, 77-112. [CrossRef] [PubMed]

109. Squarespace. Innovating for Sustainability: A Guide for Executives. Available online: https://static1.squarespace.com/static/ 5d5156083138fd000193c11a/t/5d63f7ad6609340001d2f739/1566832566189/NBS-Executive-Report-Innovation.pdf (accessed on 3 June 2021). 